\author{
Determinants of Hotel Property Prices \\ Jack B. Corgel* and Crocker Liu \\ Cornell University \\ Robert M. White \\ Real Capital Analytics
}

Published in: Journal of Real Estate Finance and Economics (2015), 51, 415-439.

J. B. Corgel (*corresponding author), School of Hotel Administration, Cornell University, Ithaca, NY, 14853. email: jc81@ cornell.edu

C. Liu, School of Hotel Administration, Cornell University, Ithaca, NY 14853

R.M. White, Real Capital Analytics, New York, NY. 


\begin{abstract}
Pricing commercial real estate has its foundations in present value theory. Recent improvements for accessing transaction data have stimulated interest in commercial property hedonic pricing models, the structures of which follow traditions in single-family real estate in that the implicit prices of property characteristics and site-specific variables represent city and national market conditions. Adding present value variables has become increasingly common to account for general market conditions. We test two hedonic pricing models; one that follows the residential tradition and another that departs by incorporating city-specific net operating incomes and the discount rates. Modeling prices in these alternative ways allows for recognition of the relative contributions of property, city, and capital market determinants. Empirical testing relies on a sample of hotel transactions from 2005-2010. The responsiveness of hotel cash flows to market changes is an important consideration. We find that models with property characteristics perform about the same as models that also include present value variables. A plausible explanation for this phenomenon is that implicit prices corresponding to property characteristics and site-specific variables appear to reflect income streams associated with city and nationwide economic conditions.
\end{abstract}

Keywords: commercial real estate, hedonic model, hotel 


\section{Determinants of Hotel Property Prices}

\section{Introduction}

A recent study by Ghysels et al. (2007) suggests that the discounted cash flow model might be more suitable than the traditional hedonic model in pricing commercial real estate. The authors also find that property and local economic factors account for only a modest portion of the variation in capitalizations rates. Given these results, a natural question that arises is whether the traditional hedonic model can be improved upon by incorporating capital market factors since the value of commercial real estate ex-ante should be affected both by property specific characteristics, and by the macroeconomic inclusive of capital market conditions at city or even national level. While intuitive, this question has not been explored in the previous literature to our knowledge. To address this question, we test a hedonic pricing model for commercial real estate (CRE) that generates implicit prices from property attributes together with implicit prices of both city market net rents and capitalization rates consistent with present value theory. Expost, we find that the performance of the traditional hedonic model is similar in performance to a modified hedonic model which also includes capital market variables even though financial variables have a modest correlation at best with property attributes. It appears that the implicit prices of property attributes are time varying and not only capture fixed location income streams but also income streams associated with city and nationwide economic conditions.

We estimate the model parameters without the Rosen (1974) equivalent of an underlying utility theory for investment in differentiated CRE attributes. Instead we assume that property attribute coefficients represent the marginal utilities received from additional units of these attributes offered at unique locations in line with urban economic theory. The implicit prices thus serve as proxies for unobserved, endemic property net rents. Hedonic modeling for CRE has 
closely followed the housing literature by relying on property-specific and transaction-specific characteristics for price prediction. Beginning with Hoag (1980), in one of earliest published CRE hedonic adaptations, there has been recognition that CRE transaction prices derive from macroeconomic and regional economic influences in addition to, and independent of, property fundamentals and locations.

A model we test uses city market net rents and capitalization rates together with property attributes, which allows us to examine the incremental determinants of CRE transaction prices across three main effects: (1) net rental for the property (2), net rental for the city market, (3) the city and national capital market. Accordingly, we assess the relative contributions of systematic (i.e., city and national) and unsystematic (i.e., property) value determinants. The econometric approach we use addresses colinearity and endogeneity issues that may arise as the result of mixing these effects within the same model.

The various property types that comprise the investible universe of CRE share many common features. Each type is subject to the same land rent conditions that determine capital and land contributions; CRE is similarly treated in the capital markets (Gyourko 2009). Property types also embody idiosyncratic characteristics. These unique features originate from endemic physical attributes and institutional arrangements found in specialized contracts (i.e., lease provisions) - the effects of which on space market rents, property prices, and securitized asset prices have been subjects for a large number of studies. ${ }^{1}$

We focus on the hotel property type for estimating our models by utilizing transaction information from U.S. markets. Hotels have a highly visible presence in cities despite only comprising about $10 \%$ of the CRE universe (Florance et al. 2010 and Prudential, 2009). Among

\footnotetext{
${ }^{1}$ One topical example is Eichholtz et al. (2010) who find that office buildings with a 'green rating' sell at a three percent premium relative to identical properties, where 'identical' is determined from a hedonic specification including multiple controls.
} 
the approximately 130 NAREIT member equity REITs, less than 20 own hotel portfolios. These facts may explain why hotel asset pricing and market behavior have not been heavily researched. The scarcity of hotel real estate data is another barrier. For example, only in recent years has NCREIF maintained a hotel index; and even now the number of properties in this index is small relative to other NCREIF property-specific indexes.

Hotel real estate valuation raises some intellectually interesting questions; the answers to which have possible implications for the general case of CRE investment analysis and valuation. The absence of long-term leases to secure income streams is the most often-cited point of differentiation from other CRE. This institutional arrangement provides hotel management with the ability to reset many room rates on a daily basis and thus offers opportunities to grow income in synchronization with upward movements of inflation and the market. ${ }^{2}$ Also, this process should symmetrically operate in reverse in down markets, albeit not necessarily with the same immediacy. ${ }^{3}$ Short-term rental raises controversial issues about cash flow risk (Quan et al. 2002), franchising effects (O’Neill and Mattila 2010), and management contributions to cash flow generation (Brady and Conlin 2004). Given minimal contract frictions, hotel markets provide a natural setting for examining the sensitivity of fixed-location income streams and asset prices to changes in the city and national economic conditions.

A final point of differentiation comes from the fact that nearly $60 \%$ of the over 52,000 U.S. hotels who report their operating performance to data aggregator Smith Travel Research (STR), and an even larger share of investment quality properties, operate with recognizable

\footnotetext{
${ }^{2}$ Hotels catering to business travelers may have forward contracts with corporations that establish room rate on an annual basis and sometimes for a meaningful number of room nights. Also, many hotels use online travel agents to which they pre-sell rooms. Hence the general statement that hotel management has the ability mark rents to market is compromised for some hotels.

${ }^{3}$ One of the issues debated in the hotel management literature involves the process of room rate 'discounting' during down markets. See Croes and Semrad (2012) for recent evidence and literature review.
} 
brands (Smith Travel Research 2012). Brand sponsors (aka franchisors) impose strict design and construction standards that introduce considerable homogeneity within the set of like-branded properties. Sponsors, such as Choice, Hilton, Hyatt, Marriott, Intercontinental, Starwood, and Wyndham, require property owners to maintain uniform quality standards during franchise contract periods. Failure to maintain these standards may result in license termination. Brand standards therefore provide 'built-in' quality controls across properties of the same brand and same market segment that are similar in nature to houses within the same neighborhood, but in contrast to other CRE property types. Brands from different sponsors tend to cluster into competitive national and city markets which results in similar physical and operational features across brands within the same market segment or 'chain scales'. ${ }^{4}$ This clustering suggests that hotels in the same market segment, although differentiated by brand, serve as close substitutes to one another.

\section{Rationalization for an Alternative Approach}

Location fixity, durability, and the absence of continuous trading place a greater importance on modeling real estate prices relative to traded financial assets and commodities. Because so much attention has been directed to real estate valuation model development, it is not surprising that different views have emerged over the conceptual and technical matters related to model construction. Importantly, an imaginary line delineates the border between relative and absolute modeling approaches for real estate valuation as it does in corporate valuation (Damodaran 2002).

\footnotetext{
${ }^{4}$ STR defines these market segments into collections of brands know as chain scales. The six chain scales are luxury, upper-upscale, upscale, upper-midscale, midscale, and economy.
} 
Without the benefit of observable market rents, the pricing of owner-occupied housing relies on relative valuations. ${ }^{5}$ Present value models were almost exclusively used for CRE valuation until recent decades when new and improved transaction data bases sparked interest in hedonic and repeat-sale model forms borrowed from residential property valuation and price indexing. The portability of housing hedonics to CRE is far from direct. Fewer comparable transactions typically occur in the CRE markets per period than in housing markets. The homogeneity of houses is known to be greater than most types of commercial properties hence CRE hedonic valuations require additional controls to conform to the law of one price. Importantly, the conceptual foundations of buyer and seller motivations in housing compared to CRE hedonic valuations depart in an economically significant way despite sharing urban economics principles.

Hedonic theory enhanced by Rosen (1974) Epple (1987), and Lancaster (1966) from early applications by Court (1939) and Griliches (1961, 1971) assumes that the prices of differentiated consumer products derive from the implicit prices of the attribute collections that comprise these products. Obviously no transactions occur for any one attribute (e.g., bedrooms in houses) so the prices of characteristics are never independently observed. Aggregate housing demand and supply ultimately determine attribute marginal contributions to aggregate prices. The demand and supply drivers for CRE (e.g., CBD location) may differ in meaningful ways from the determinants of home prices (e.g., proximity to good schools not likely a factor in CRE investment).

\footnotetext{
${ }^{5}$ Muth (1960) developed a theory of housing demand based on the service flows received by occupants. BOne unit of housing service is defined as that quantity of service yielded by one unit of housing stock per unit of time. The price per unit of housing service, or rent, is the price paid by consumers for the flow of services from one standard house peer unit of time (pp. 32-33).^ The value of a house then becomes the present value of the flow of services net of expenses. Given the difficulty of converting and building pro forma of housing service flows in terms of monetary rental flows paid by consuming owner occupants (i.e., price time quantity of housing services), valuation models based on financial economics principles never emerged. Hedonic models serve to standardize units of housing services.
} 
In Rosen (1974) two-stage model, consumer demand determinants, such as income, are important for estimating implicit prices - the consumers' marginal willingness to pay for each attribute. The coefficient estimates from CRE hedonic models may be interpreted in a similar way to marginal utilities investors receive from additional units of attributes in much the same way as housing attribute implicit prices are interpreted by consumers. However, an investor utility theory for heterogeneous investment properties and their attributes is not well developed. The literature on heterogeneous buyer behavior (Bokhari and Geltner 2011), seller behavior (Haurin et al. 2010), and investor sentiment (Clayton et al. 2009) is emerging, but nascent at present. Because investors achieve wealth maximization objectives by obtaining rights to future net rents, it is reasonable to assume that investors achieve these objectives through ownership of CRE attributes and thus the aggregation of attribute implicit prices correspond to total net rents. The question we pursue here is whether or not the implicit prices of property characteristics and site-specific variables incorporate city and national market conditions believed to influence CRE prices or do other unique independent variables needed to be included to account for these influences. Our results indicate that city and national market conditioning variables add little to the explanatory power of the CRE hedonic model.

The CRE pricing model we test uniquely incorporates city net rent and capital market pricing linked to national net rents together with a typical set of property attributes that conceptually relate to property-specific net rents. Present value and urban economic theories taken together suggest that general levels of rents and capitalization rates of cities where properties are located, relative properties locations within cities, and the physical characteristics of the property determine the asset prices. Endogeneity arises in the hedonic model we test as the 
result of introducing city net rents so we estimate model parameters using two-stage least squares in which net rent and price are endogenous.

We find that including only property and site-specific characteristics in the hedonic model following the residential modeling convention provides about the same explanatory power as a model that combines property, city income, and capital market characteristics. Both models explain between 75 and $80 \%$ of the variation in hotel asset prices after controlling for transaction effects, brand/quality, and time trend. We conclude that the implicit prices of the propertyspecific attributes absorb changes in city and national market conditions over time since the model parameters are estimated with prices that continuously change with these conditions.

The remainder of the paper is organized as follows. "Related Literature" contains a review of literature - its relevance and findings. In "Model" we present a model that sets up our empirical testing of hedonic models. "Research Design and Method" describes the data and explains variable construction. The methodology and econometric issues also are discussed in this section. "Results" presents results from the analysis of hotel transaction data. Concluding remarks appear in the final section.

\section{Related Literature}

Our interests in the related literature first lie with the hedonic modeling approaches generally followed for pricing single-family homes and CRE; and secondarily with advancements in explaining variation in hotel property prices. With respect to CRE adaptations, it has become increasingly clear that treating CRE as a composite asset class introduces aggregation bias - macro parameters deviating from the averages of the component micro parameters (Theil 1954). Differences in risk and return relationships among various property 
types are demonstrated in diversification studies (Fisher and Liang 2000 and Cheng and Roulac 2007). Other studies show marked differences across property types in the ability of capitalization rates to predict future returns (Plazzi et al. 2010), and patterns of construction cycles as well as correlations with the business cycle (Wheaton 1999). This evidence suggests that different economic determinants of prices and returns associated with different CRE property types justify customized valuation model development for major property types.

By comparison, the volume of hedonic pricing research in single-family housing far exceeds the number of similar studies for CRE property types. Given the absence of both observable market rents and a wealth maximizing investment perspective, housing models usually do not blend present value and urban economic theory. Of the housing studies that rely on present value concepts, Meese and Wallace (1994) find that modeled values may deviate from observed house prices in the short run.

Since the early 1980s, advancements in CRE hedonic pricing occurred to the extent that models have been applied to examine a wide variety of practical issues including apartment age restrictions (Guntermann and Moon 2002), rent concessions (Sirmans et al. 1990), and technological change (Colwell and Ramsland 2003) to cite a few. Dermisi and McDonald (2010) and Wiley and Wyman (2012) provide updated detailed reviews of this literature. Beginning with Hoag (1980), CRE hedonic models began incorporating economic measures, such as national employment and GDP, to control for differences in macroeconomic conditions at the times of sales. These variables enter hedonic equations without direct links to asset pricing theory and, except for Lockwood and Rutherford (1996) who use LISREL to correct for econometric problems; they also may introduce multi-colinearity problems resulting from mixing national and local economic determinants within the same model. The introduction of market-wide controls is 
not always beneficial. Dermisi and McDonald (2010), for example, include both the office property and market vacancy rate in their hedonic model. Property vacancy is statistically significant while market vacancy is insignificant leading to the conclusion that “... investors are more inclined to acquire properties due to their specific characteristics and occupancy level rather than the overall market condition (p.13).”

For hotel properties, Corgel $(1997,2007)$ reports hedonic results with disaggregate transaction data using similar sets of property and location characteristics and measures of local market economic strength, such as ZIP or county employment and income. ${ }^{6}$ These semi-log regressions explain large percentages of variation in sale price. Most property and all local market economic variables are correctly signed and statistically significant. None of the equations include either city NOI or capital market effects, although local economic variables proxy with error for local area NOI. Recently, Blal and Graf (2013) estimate a model using over 10,000 hotel sales and a set of conditioning variables and explanatory power (i.e., $R^{2}=0.72$ ) not much different than earlier studies. They find that hotels with property characteristics measurably different from the norm sell at discounts. Another recent working paper (Beracha et al. 2013) follows an approach with findings similar to ours in that market-wide variables tend to be statistically significant in the hedonic model but add little to the overall explanatory power. Explaining variation in property capitalization rates represents an alternative path to understanding CRE asset market pricing. Nearly all of these studies use aggregate, appraisalbased capitalization rate data. Sivitanidou and Sivtanides (1999) and Jud and Winkler (1995), for example, estimate equations with transaction-generated capitalization rates, but use periodic averages that do not allow for property-level quality controls. In contrast, McDonald and

\footnotetext{
${ }^{6}$ O'Neill (2004) estimates a hedonic price equation for hotels that includes both hotel financial performance variables and local market controls, but he only reports results for financial performance variables.
} 
Dermisi $(2008,2009)$ build a capitalization rate models with disaggregated transaction data so that local economic, national economic, and property characteristics appear in the same model. They find that local and national economic forces effect risk-free rates, risk premiums, and rental growth run (i.e., Gordon Growth model components) through the capitalization rate. A review in Chaney and M. Hoesli (2012) traces this literature from the late 1980s to present and discusses its shortcomings.

To the best of our knowledge, this study is among the first to test a hedonic model for explaining variation in CRE prices rooted in both urban economic and present value theories while recognizing the econometric problems of estimating parameters of such a model. This approach allows us to separate the effects of property fundamentals, city markets, and the macrolevel capital market. Ghysels et al. (2007) conclude that ... "commercial real estate prices are better modeled as financial assets and that the discounted rent model might be more suitable than traditional hedonic models, at least at the aggregate level (p. 472-3)," They report that less than one-third of the variation in capitalization rates is explained by property and local economic variables. Our results give credence to traditional hedonic pricing of CRE, but do not directly contrast hedonic and DCF predictions. We report that present value model components add little in a hedonic framework.

\section{Model}

Discounting future net rents to generate current present values is deeply rooted in financial economic theory as adapted for CRE valuation. The basic form of the model is

$$
V_{0}=\sum_{t=1}^{N} \frac{N O I_{t}}{(1+r) t}
$$


where $\mathrm{NOI}_{t}$ is the net operating income at the end of period $t$ and $r$ is the risk-adjusted discount rate. Following McDonald (2005) and multiplying by $(1+r)$, gives

$$
\mathrm{V}_{0}(1+\mathrm{r})=\mathrm{NOI}_{1}+\mathrm{V}_{1}
$$

Rewriting this equation gives,

$$
\mathrm{V}_{0}=\left(\mathrm{NOI}_{1}+\Delta \mathrm{V}\right) / \mathrm{r} \text {, }
$$

where $\Delta \mathrm{V}=\mathrm{V}_{1}-\mathrm{V}_{0}$

The period-zero capitalization rate, $C_{0}$, comes from solving Eq. (3), as follows

$$
\mathrm{C}_{0}=\mathrm{NOI}_{1} / \mathrm{V}_{0}=\mathrm{r}-\left(\Delta \mathrm{V} / \mathrm{V}_{0}\right)
$$

The expression for $V_{0}$ can be written in the form below assuming the terminal capitalization rate equals the initial capitalization rate and the Gordon Growth Model takes a general form with percent change in value as follows

$$
\mathrm{V}_{0}=\left(\mathrm{NOI}_{1}+\Delta \mathrm{V}\right) /\left[\mathrm{C}_{0}+\left(\Delta \mathrm{V} / \mathrm{V}_{0}\right)\right]
$$

We present $\mathrm{NOI}_{1}$ as the composite of systematic effects from the local market and idiosyncratic property-specific effects. Thus,

$$
\mathrm{NOI}_{1}=\mathrm{NOI}_{\mathrm{m} 1}+\mathrm{NOI}_{\mathrm{i} 1}=\left(\mathrm{R}_{\mathrm{m} 1}-\mathrm{E}_{\mathrm{m} 1}\right)+\left(\mathrm{R}_{\mathrm{i} 1}-\mathrm{E}_{\mathrm{i} 1}\right)
$$

where $\mathrm{NOI}_{\mathrm{m} 1}$ and $\mathrm{NOI}_{\mathrm{i} 1}$ represent the NOIs of the local market and individual property, respectively. Each NOI has endemic rent (i.e., $R_{m}$ and $R_{i}$ ) and expense (i.e., $E_{m}$ and $E_{i}$ ) components.

Unobservable property $\mathrm{NOI}_{\mathrm{i} 1}^{*}$ is estimated from location and physical property attributes, $\mathrm{Z}_{\mathrm{i}}$, as

$$
\mathrm{NOI}_{\mathrm{i} 1}^{*}=\mathrm{f}\left(\mathrm{Z}_{\mathrm{i}}\right)
$$

The final expression for $\mathrm{V}_{0}$ becomes

$$
\mathrm{V}_{0}=\left[N O I_{m 1}+\mathrm{NOI}_{\mathrm{i} 1}^{*}+\Delta V\right] /\left(C_{0}+\left(\Delta V / V_{0}\right)\right)
$$


Holding to the assumption that the terminal capitalization rate equals the initial capitalization rate the denominator of Eq. (8) may be represented by the discount rate, r. All of the parameters in Eq. (8) are estimated using a hedonic specification in which the local market NOI effect is represented, the city rate for present valuing captures both national capital market influences and local risk premiums, property NOI effect is included, and trend and transaction specific characteristics are controlled for through the time-series and other dummy variables, $\mathrm{D}_{\mathrm{t}}, \mathrm{D}_{\mathrm{k}}$

$$
\ln \left(\mathrm{P}_{\mathrm{i}}\right)=\alpha+\left[\beta_{1}^{*}\left(\mathrm{NOI}_{\mathrm{m} 1}\right) / \beta_{2}^{*}\left(\mathrm{r}_{0}\right)\right]+\beta_{3} \mathrm{Z}_{\mathrm{i}}+\mathrm{f}\left(\mathrm{D}_{\mathrm{t}} \ldots \mathrm{D}_{\mathrm{n}}, \mathrm{D}_{\mathrm{k}}\right)+\mathrm{e}_{\mathrm{i}}
$$

Because the present value model structure embedded in Eq. (9) is non-linear we take the natural $\operatorname{logs}$ of both $\mathrm{NOI}_{\mathrm{m} 1}$ and $\mathrm{r}_{0}$. The final form is,

$$
\ln \left(\mathrm{P}_{\mathrm{i}}\right)=\alpha+\beta_{1}^{*} \ln \left(\mathrm{NOI}_{\mathrm{m} 1}\right)-\beta_{2}^{*} \ln \left(\mathrm{r}_{0}\right)+\beta_{3} \mathrm{Z}_{\mathrm{i}}+\mathrm{f}\left(\mathrm{D}_{\mathrm{t}} \ldots \mathrm{D}_{\mathrm{n}}, \mathrm{D}_{\mathrm{k}}\right)+\mathrm{e}_{\mathrm{i}}
$$

Econometric issues encountered when estimating Eq. (10) arise from the possibility that $\mathrm{NOI}_{\mathrm{m} 1}$ is correlated with $\mathrm{e}_{\mathrm{i}}$. We discuss this endogeneity problem in a subsequent section.

\section{Research Design and Method}

\section{Data}

The hotel data primarily come from Real Capital Analytics (RCA). This firm collects transaction prices and associated property characteristics for U.S. commercial property sales greater than \$2.5 million. The sample period begins in January 2005 and ends in December 2010. Data from CoStar, PKF Hospitality Research, and STR augment the RCA data. The subsequent section on variable construction discusses the various uses of these supplemental databases. 


\section{Variable Construction}

The property characteristics appearing on the right side of our hedonic equations account for the variation in selling prices of a unique property type although some are common to other CRE models. We include the effective age (EA) — calculated as the year of sale subtracted from the year of renovation, the number of rooms (RM), a landmark property dummy (DLAND) which equals one if the hotel is designated as a historical landmark and zero otherwise. Two location dummies also enter the equations. The first of these variables captures whether the hotel is located next to water (DH2O) such as beachfront property while the second one denotes a CBD hotel location (DCBD). We also include a dummy to indicate expected and meaningful (i.e., in terms of scale) renovations associated with the sale event (DRENO).

Transaction-specific effects may influence hotel sale prices so controls appear in the equations for REIT hotel buyers (DREIT), a positive clientele effect mentioned in financial press reports during the period, and if individual hotels changed ownership as part of portfolio transactions (DPORT). ${ }^{7}$ The sign on the DPORT coefficient is ambiguous because the composition of the portfolio may result in a single property's price being greater than or less than the price if the hotel was sold independent of other assets.

Based on economic institution and findings in the real estate asset pricing literature, we expect an inverse relationship between effective age and transaction prices of hotels. Positive relationships are presumed between selling prices and the number of rooms, landmark designation, locations near water and in the CBDs, planned hotel renovations, and REIT buyers.

To measure difficult to observe hotel attributes such as amenity and service quality, a market segment dummy variable series is used for differentiation of lower from higher quality

\footnotetext{
${ }^{7}$ The recorded price for a property sold as part of a portfolio is the price reported to RCA. Sometimes RCA make an allocation of the portfolio price to each property.
} 
hotels. These are: luxury (LUX), upper upscale hotels (UUPS), upscale hotels (UPS), upper midscale hotels (UMID), midscale hotels (MID), and economy (ECO) hotel market segments (i.e., chain scales). ${ }^{8}$ We expect the hotel prices to increase with hotel quality. As discussed in the introduction, brand standards result in property homogeneity and brands clustered within the chain scales also are of similar quality.

The extent of economic activity in the immediate surrounding area of the sold hotels may not be adequately controlled for by the variables discussed above. Hence, the daytime employment base (i.e., number of employees) within a three mile radius of the hotel location was collected from CoStar and introduced into the hedonic equation (NEMP). The higher the daytime employment base, the greater the potential demand for hotel rooms and logically higher selling prices. A dummy variables series starting in 2006 (T06) and ending in 2010 (T10) accounts for time trend. ${ }^{9}$

City discount rates come from Real Estate Research Corporation. A city NOI variable is constructed using PKF and STR total revenue and expense ratio data during each year. We adjust revenue by one minus the expense ratio of properties' respective market segment to link the city NOI to each property. The variable construction equation is as follows,

$$
\mathrm{NOI}_{i t}=\operatorname{Rev}_{\text {City,t }}^{*}\left(1-\mathrm{OR}_{\text {Market Segment i,t }}\right) \text {, }
$$

where $\mathrm{NOI}_{\mathrm{it}}$ is the city NOI assigned to property $\mathrm{i}$ in period $\mathrm{t}, \operatorname{Rev}_{\mathrm{City}, \mathrm{t}}^{*}$ is the city total revenue in period $t$, and $\mathrm{OR}$ is the operating ratio for the applicable chain sale for property $i$ in period t.

\footnotetext{
${ }^{8}$ Market segments are defined using STR classification chain scale system. This system is detailed in a subsequent section. The luxury hotel dummy is the omitted variable.

${ }^{9}$ The 2005 dummy is the omitted variable.
} 


\section{Results}

Table 1 presents descriptive statistics for a sample of 623 hotel real estate sales that transacted in the U.S. from 2005 through 2010. As shown in Panel A, the sample includes both large (i.e., $\mathrm{RM}_{\max }=1348$ ) and small hotels (i.e., $\mathrm{RM}_{\min }=21$ ). The NOIs and discount rates are for the city in which the transaction was completed. Statistics for property characteristics and transaction-specific variables appear in Panel B. Note that the transactions are spread across the six STR chain scales; all dummy variables are well distributed; and that the 2008-2009 financial crisis and recession lowered transaction volume.

\section{Hedonic Estimates}

Our first set of implicit price estimates comes from running the data through the standard hedonic model with property attributes, transaction characteristics, and present value model variables-NOIs and discount rates. Table 2 presents the results from estimating three alternative models. As is often the case in single-family and CRE hedonic estimations the semi-log functional form provides the best fit of the data. Model I includes property characteristics, immediate surrounding area effects, transaction-specific measures, and time dummies. This conventional hedonic specification explains nearly $76 \%$ of the variation in hotel transaction prices. All variables have the expected signs and only effective age squared and two of the time dummies have coefficients that are not significant at the 0.10 level or better. In Model II, we remove the property characteristics and immediate area measures and introduce the logs of the NOI and discount rate while continuing to keep in place the controls for transaction effects and time trend. Only city NOI and the REIT buyer dummy are statistically significant in this regression. Together the financial variables and controls account for less than $40 \%$ of the variation in hotel transaction prices. 
Model III mixes the traditional hedonic variables with financial variables. Interestingly, the coefficient vector of traditional hedonic variables differs only slightly from the Model I vector. The sizes and t-statistics of city NOI and discount rate, however, are markedly different in this specification relative to Model II. The coefficient and t-statistic of city NOI, while remaining correctly signed, measurably decline in size. Also, the discount rate becomes negative consistent with theory and statistically significant. Notwithstanding, the explanatory power of this model is only slightly improved over the standard hedonic model as shown by the $\mathrm{R}^{2}$ of 0.7747 compared to 0.7594 . We interpret the results from this estimation as an indication that modeling hotel property prices may be relatively unaffected by introducing market effects in the same equation with property and area-specific variables as evidenced by the stability of the coefficient vector and lack of $\mathrm{R}^{2}$ enhancement. We also suspect that possible econometric issues from mixing these variables within the same model may not be generating the correct parameter estimates and regression statistics.

With respect to the econometric issues, we have unanswered questions about correlations among regressors in these models, especially in Model III. First-order correlation coefficients and variance inflation factors appear in Table 3. The correlation between NOI and NEMP appears high, yet not alarmingly so, and the variance inflation factors for EA and EA ${ }^{2}$ approach the rule-of-thumb critical level of 10.0 (Kennedy 2003, p.213). As a test, we remove EA and EA ${ }^{2}$ from Model III; this action results in very minor effects. In summary, the statistics presented in Table 3 do not raise meaningful concerns regarding the independence among the regressors, hence we conclude that our models do not violate the linear independence assumption. 


\section{Endogeneity and 2-Stage LS Estimation}

In Eq. (9) restated below, hotel prices are modeled as a function of city $\mathrm{NOI}\left(\mathrm{NOI}_{\mathrm{m} 1}\right)$, property specific characteristics $\left(Z_{i}\right)$, city discount rate $\left(r_{0}\right)$, time trend of price changes $\left(D_{t}\right)$, and transaction-specific price determinants, $\mathrm{D}_{\mathrm{k}}$.

$$
\ln \left(\mathrm{P}_{\mathrm{i}}\right)=\alpha+\left[\beta_{1}^{*}\left(\mathrm{NOI}_{\mathrm{m} 1}\right) / \beta_{2}^{*}\left(\mathrm{r}_{0}\right)\right]+\beta_{3} \mathrm{Z}_{\mathrm{i}}+\mathrm{f}\left(\mathrm{D}_{\mathrm{t}} \ldots \mathrm{D}_{\mathrm{n}}, \mathrm{D}_{\mathrm{k}}\right)+\mathrm{e}_{\mathrm{i}}
$$

While we show that the variables representing these determinants are not highly correlated and OLS generates reasonable parameter estimates and high although not extremely high R-squares, aggregate city NOI likely will not capture all the effects of market influences on hotel property prices. Thus, omitted regressors may be correlated with included regressors and with the error term, $\mathrm{e}_{\mathrm{i}}$. This observation suggests that $\mathrm{NOI}_{\mathrm{m} 1}$ is endogenous and its coefficient, $\beta_{1}$, is inconsistent. We address the potential endogeniety problem in Model III by re-estimating Eq. (9) using the control-function approach that involves introducing instruments in a first-stage NOI regression. The changes in the selected instrumental variable(s) must be associated with changes in NOI, but not associated with changes in regressors and $\mathrm{P}_{\mathrm{i}}$, except through NOI.

Two instrumental variables enter the first-stage regression. To account for possible differences in city hotel demand mix (i.e., business group, and transient), we include a dummy variable (DGATE) to reflect whether the sold hotel is located in a gateway city. Cities that we define as gateway cities include Atlanta, Chicago, Dallas, Los Angeles, New York, Miami, San Francisco, and Washington DC. Table 3 shows the first-order correlation coefficient between DGATE and NOI equals 0.45. This result is not surprising since both DGATE and NOI represent citywide effects. The other instrument is the city unemployment rate (UEMPR), a variable that has not appeared in hotel asset pricing equations presented in the literature, but may influence 
city NOI through the labor expense line. Equation (12) presents the first-stage estimating equation.

$$
\mathrm{NOI}_{\mathrm{m} 1}=\lambda+\gamma_{1} \text { DGATE }_{\mathrm{i}}+\gamma_{2} \text { UNEMR }_{\mathrm{i}}+\mathrm{f}\left(\mathrm{D}_{\mathrm{t}} \ldots \mathrm{D}_{\mathrm{n}}\right)+\mathrm{u}_{\mathrm{i}}
$$

In the first-stage estimation both instruments are correctly signed, but only the DGATE coefficient is statistically significant $\left(\mathrm{R}^{2}=0.30\right)$. Table 4 presents the second stage results from data for the sample of 623 U.S. hotel sales. Comparing these results to those reported in Table 2 for Model III, most coefficients are nearly the same magnitudes and significance levels. The estimated NOI coefficient of 0.3124 is larger from this analysis versus 0.1702 from OLS which is consistent with our presumption of endogeniety bias. The coefficient of NEMP becomes smaller with the more consistent estimation of NOI. As shown in Table 3, these measures have a correlation coefficient of 0.46 attributable to the fact that the three mile radius from the hotel location lies within city boundaries. Unexpectedly, the coefficient for the discount rate becomes statistically insignificant while maintaining the theoretically correct negative sign. Finally, the Rsquared (i.e., 0.7711 and 0.7747$)$ and root mean square error (i.e., 0.5457 and 0.5418 ) remain virtually the same in the 2 SLS run relative to OLS.

\section{Variation in Implicit Prices}

The weak explanatory power of city and capital market variables may be because of any one or a combination of alternative explanations. First, as Dermisi and McDonald (2010) contend CRE buyers and sellers may transact based on idiosyncratic property features and performance measures without much recognition of city and national markets conditions. This position recognizes that 'good' properties can command high prices in poor markets and 'bad' properties low prices in good markets. Second, the implicit prices of property-specific variables 
absorb, and move in concert with, general market conditions as do the prices of composite good. The counter argument would be that the estimated implicit prices only reflect differences in the quantities and qualities of the CRE that transacted during a particular period, given that the composition of properties sold can be quite different from period to period.

Table 5 presents the range of implicit prices for most important property-specific variables in our single-stage regression. These estimates come from running the regressions only with transaction information from each year in during the sample period, 2005 through 2010. Some of the ranges are fairly broad while others narrow. Unfortunately we are unable to determine whether periodic differences in these implicit prices originate from sample composition differences or changes in underlying market conditions from 2005 through 2010.

\section{Robustness Check - Results by Chain Scale}

The universe of approximately 52,000 hotels and nearly 5,000,000 rooms assembled by data aggregator STR is widely viewed as 'the U.S. hotel industry'. This assemblage excludes properties with fewer than 20 rooms and includes most hotels with brand affiliations and many independent hotels inside the U.S. boundaries. The STR universe is organized into six chain scale divisions each consisting of branded hotels of similar quality and ADR plus a large independent hotel category. The number (percent) of hotels in each chain scale is as follows (Smith Travel Research 2012):

Luxury - 307 (0.6\%), examples include Ritz-Carlton and Four Seasons.

Upper Upscale - 1,513 (2.9\%), examples include Hyatt and Westin.

Upscale - 3,760 (7.2 \%), examples include Hilton Garden Inn and Hotel Indigo.

Upper Midscale - 8,776 (16.8\%), examples include Hampton Inn and Fairfield Inn. 
Midscale - 5,336 (10.2\%), examples include Quality Inn and Red Lion.

Economy - 10,363 (19.9\%), examples include Motel 6 and Microtel Inn.

Independent $-22,098(42.4 \%)$.

These data reveal that the hotel industry is not an evenly distributed collection of operating businesses. Many more U.S. hotels operate in the economy segment than other chain scales. Also, a large number of independent hotels would logically fall into the economy segment if classified according to chain scales along price and quality lines. To conduct robustness checks on our results from analyzing aggregate data we disaggregate the hotels in our sample into chain scales and re-estimate the price equations. Because of sample size limitations we combine the six chain scales into three classifications - luxury and upper upscale $(N=140)$, upscale and upper midscale $(N=254)$, and midscale and economy $(N=229)$. Independent hotels in the sample are assigned to a chain scale by examining their room size and amenities.

Results from re-estimating the hedonic pricing models (i.e., single and two stages) for the three hotel market segment classifications appear in Table 6 through Table 8. Focusing on the 2SLS estimates, the coefficient sizes and significance along with regression statistics exhibit several dissimilarities across the four sets of equations - full sample (Table 4), luxury/upper upscale (Table 6), upscale/upper midscale (Table 7), and midscale/economy (Table 8). A bulleted summary of the differences is as follows:

Full Sample Compared to Luxury/Upper Upscale

- The R-squared is somewhat lower for this sub-sample (i.e., 0.5860 vs. 0.7711 ).

- Neither of the present value variable coefficients are significant.

- Surprisingly, age, CBD location, and landmark status are not important for explaining variation in high-end hotel property prices. 
- Only the number of rooms and water location have significant coefficients among the property characteristics.

- Not surprisingly, REIT buyers are important for price determination and the portfolio variable coefficient is not significant in the sub-sample regression. Higher-end hotels have attracted REIT buyers, but generally sell in one-off transactions.

\section{Full Sample Compared to Upscale/Upper Midscale}

- $\quad$ The R-squared is somewhat lower for this sub-sample (i.e., 0.5829 vs. 0.7711).

- Both present value variable coefficients are significant.

- The remaining coefficient vector in this sub-sample closely aligns with that of the full sample.

\section{Full Sample Compared to Midscale/Economy}

- The R-squared is noticeably lower for this sub-sample (i.e., 0.5361 vs. 0.7711).

- The NOI variable coefficient is insignificant for this sub-sample, but the discount rate coefficient is insignificant.

- Variable coefficients that relate more to higher-price hotels are not significant in this regression involving lower-price hotel transaction information. These are; CBD location, landmark, and water proximity.

- The coefficient on the REIT buyer variable is unexpectedly significant.

Across chain scale regressions the results for estimated coefficients for non-property variables - NOI and $\mathrm{r}$ - show considerable inconsistency. Many of the estimates for the propertyand area-specific variables can be explained by intuition. The robustness check generally validates the use of traditional hedonic approaches to hotel real estate pricing, but does not lend 
much support for including non-property specific variables among regressors. Notably, the same cautions about aggregation bias across CRE property type pricing models applies to different hotel quality strata. Specifically, the vector of explanatory variables introduced to predict highprice hotels will likely not work best for hotels in the mid-price and low price chain scales.

\section{Conclusion: Property, City, and National Market Pricing Effects}

Hedonic studies of commercial real estate pricing that report the relative importance of property characteristics (i.e., physical and location), local market economics, and national financial conditions have focused on accounting for variations in both property prices and capitalization rates. These studies offer conflicting conclusions. Sivitanidou and Sivtanides (1999) and McDonald and Dermisi (2008), for example, find that property attributes and local economics are the most important drivers of capitalization rate variation. In contrast, Ghysels et al. (2007) and Chervachidze and Wheaton (2013) place the majority of weight on macroeconomic conditions. Recently Dermisi and McDonald (2010), from an office property hedonic pricing study, conclude that investors are more inclined to acquire properties due to their specific characteristics and not general market conditions.

The hotel transaction price data we analyze are suited for answering the question because of the absence of lease frictions that would impede the incorporation of local and national economic effects into prices. Our tests of a model that includes local market net rents and capitalization rates together with property attributes allows us to estimate and differentiate among a diverse set of hotel transaction price determinants. We organize potential determinants of hotel prices along the lines of the following three main effects: (1) property net rental (i.e., property characteristic proxies), (2) city market net rental, (3) the city and national capital market 
allows us to access the relative contributions of systematic (i.e., city and national) and unsystematic (i.e., property) value determinants.

We show that in a conceptual valuation modeling context that variation in hotel prices should be explained by systematic economic factors in the city and nation as well as property specific attributes that fundamentally relate to cash flow generation. This is analogous to modeling stock returns of a particular company as a function of an overall market effect, an industry effect, and an idiosyncratic factor associated with the firm. In this context, academic debates regarding the relative importance of property and macroeconomic forces on property values seem less meaningful.

Our empirical analysis does not support the inclusion of variables measuring city and national market effects. These variables add little to the explanatory power of the hedonic model. Either Dermisi and McDonald (2010) are correct in their assertion that investors largely ignore broader market indicators in favor of property-specific characteristics and financial performance or the implicit prices of endemic property attributes embody the strength of city and national markets. We report that the implicit prices of property attributes vary sometimes substantially during our study period, but we are not able to separate out the effects of different quantities and qualities of sold properties during each year from the movements in markets from year to year. Future research may answer this question. 


\section{Acknowledgements}

We wish to thank our anonymous reviewer for his comments which have significantly improved the quality of our paper. We would also like to thank the editor, James Kau for his helpful suggestions as well. 


\section{References}

Beracha, E., W.G. Hardin, \& H. M. Skiba. (2013). Hotels: markets, economics, and price, working paper, 2013.

Blal, I., \& Graf, N. S. (2013). The discount effect of non-normative physical characteristics on the price of lodging properties. International Journal of Hospitality Management, 34(1), $413-422$.

Bokhari, S., \& Geltner, D. (2011). Loss aversion and anchoring in commercial real estate pricing: empirical evidence and price index implications. Real Estate Economics, 39(4), 635-670.

Brady, P. J., \& Conlin, M. E. (2004). The performance of REIT-owned properties and the impact of REIT market power. Journal of Real Estate Finance and Economics, 28(1), 81-95.

Chaney, A. \& M. Hoesli. (2012). Transaction-based and appraisal-based capitalization rate determinants. Unpublished working paper, Swiss Finance Institute, August 2012.

Cheng, P., \& Roulac, S. E. (2007). Measuring the effectiveness of geographical diversification. Journal of Real Estate Portfolio Management, 13(1), 29-44.

Chervachidze, S., \& Wheaton,W. (2013). What determined the great cap rate compression of 2000-2007, and the dramatic reversal during the 2008-2009 financial crisis? Journal of Real Estate Finance and Economics, 46(1), 208-231.

Clayton, J., Ling, D. C., \& Naranjo, A. (2009). Commercial real estate valuation: fundamentals versus investor sentiment. Journal of Real Estate Finance and Economics, 38(1), 5-37.

Colwell, P. F., \& Ramsland, M. O. (2003). Coping with technological change: the case of retail. Journal of Real Estate Finance and Economics, 26(1), 47-63. 
Corgel, J. B. (1997). Property-by-property valuations of publicly-traded real estate firms. Journal of Real Estate Research, 14(1), 77-90.

Corgel, J. B. (2007). Technological change as reflected in hotel property prices. Journal of Real Finance and Economics, 34(2), 257-279.

Court, A.T. (1939) Hedonic price indexes with automotive examples. In The Dynamics of Automobile Demand. (99-117). General Motors Corporation, New York.

Croes, R. \& Semrad, K.J. (2012). Does Discounting Work in the Lodging Industry? Journal of Travel Research, forthcoming in print, published online March 26, 2012.

Damodaran, A. (2002). Investment valuation (2nd ed.). New York: Wiley.

Dermisi, S. V., \& McDonald, J. F. (2010). Selling prices/Sq. Ft. of office buildings in downtown Chicago - how much is it worth to be an old but class a building. Journal of Real Estate Research, 32(1), 1-21.

Eichholtz, P., Kok, N., \& Quigley, J.M. (2010). Doing well by doing good? Green Office Buildings. American Economic Review, 100(5), 2492-2509.

Epple, D. (1987). Hedonic prices and implicit markets: estimating demand and supply functions for differentiated products. Journal of Political Economy, 95(1), 59-80.

Fisher, J. D., \& Liang, Y. (2000). Is property-type diversification more important than regional diversification? Real Estate Finance, 17(3), 35-40.

Florance, A., Miller, N. G., Peng, R., \& Spivey, J. (2010). Slicing, dicing, and scoping the size of the U.S. Commercial real estate market. Journal of Real Estate Portfolio Management, 16(2), 101-118.

Ghysels, E., Plazzi, A., \& Valkanov, R. (2007). Valuation in US commercial real estate. European Financial Management, 13(3), 472-497. 
Griliches, Z. (1961). Hedonic Price Indexes for Automobiles: An Econometric Analysis of Quality Change,". In G. Stigler (Ed.), The price statistics of the federal government (pp. 173-196). Washington D.C: GPO.

Griliches, Z. (1971). Introduction: Hedonic Price Indexes Revisited. In Z. Griliches (Ed.), Price indexes and quality change (pp. 3-15). Cambridge: Harvard University Press.

Guntermann, K. L., \& Moon, S. (2002). Age restrictions and property values. Journal of Real Estate Research, 24(3), 263-278.

Gyourko, J. (2009). Understanding commercial real estate: just how different from housing is it? Journal of Portfolio Management, 2009, Special Real Estate Issue, 23-37.

Haurin, D. R., Haurin, J. L., Nadauld, T., \& Sanders, A. (2010). List prices, sale prices and marketing time: an application to U.S. housing markets. Real Estate Economics, 38(4), $659-685$.

Hoag, J. W. (1980). Toward indices of real estate values and returns. Journal of Finance, 35(2), $569-580$.

Jud, G. D., \& Winkler, D. T. (1995). The capitalization rate of commercial properties and market returns. Journal of Real Estate Research, 10(5), 509-518.

Kennedy, P. (2003). A guide to econometrics (5th). Cambridge: MIT Press.

Lancaster, K. J. (1966). A new approach to consumer theory. Journal of Political Economy, 74(2), 132-157.

Lockwood, L. J., \& Rutherford, R. (1996). Determinants of industrial property values. Real Estate Economics, 24(2), 257-272.

McDonald, J. F. (2005). The Q theory of investment, the capital asset pricing model and real estate valuation: a synthesis. Journal of Real Estate Literature, 13(3), 271-286. 
McDonald, J. F., \& Dermisi, S. (2008). Capitalization rates, discount rates, and net operating income: the case of downtown Chicago office buildings. Journal of Real Estate Portfolio Management, 14(4), 363-374.

McDonald, J. F., \& Dermisi, S. V. (2009). Office building capitalization rates: the case of downtown Chicago. Journal of Real Estate Finance and Economics, 39(4), 472-485.

Meese, R., \& Wallace, N. (1994). Testing the present value relation for housing prices: should I leave my house in San Francisco? Journal of Urban Economics, 35(1), 245-266.

Muth, R.F. (1960). The demand for non-farm housing, In A.C Harberger, The Demand for Durable Goods. (29-96). Chicago IL: University of Chicago Press.

O’Neill, J.W. (2004). An automated valuation model for hotels. Cornell Hotel and Restaurant Administration Quarterly, 45(3), 260-268.

O’Neill, J. W., \& Mattila, A. S. (2010). Hotel brand strategy. Cornell Hospitality Quarterly, $51(1), 27-34$.

Plazzi, A., Torous, W., \& Valkanov, R. (2010). Expected returns and expected growth in rents of commercial real estate. Review of Financial Studies, 23(9), 3469-3519.

Prudential Real Estate Investors. Why investors should own commercial real estate. 2009 (October).

Quan, D. C., Li, J., \& Sehgal, A. (2002). The performance of lodging properties in an investment portfolio. Cornell Hotel and Restaurant Administration Quarterly, 43(6), 81-89.

Rosen, S. (1974). Hedonic prices and implicit markets: product differentiation in pure competition. Journal of Political Economy, 82(1), 34-55.

Sirmans, G. S., Sirmans, C. F., \& Benjamin, J. D. (1990). Rent concessions and property values. Journal of Real Estate Research, 5(1), 141-151. 
Sivitanidou, R., \& Sivtanides, P. (1999). Office capitalization rates: real estate and capital market influences. Journal of Real Estate Finance and Economics, 18(3), 297-322.

Smith Travel Research (2012). U.S. Pipeline Outlook. 2012 (April 9).

Theil, H. (1954). Linear aggregation of economic relations. 1954. Amsterdam: North Holland. Wheaton, W.C. (1999) Real estate "cycles": Some fundamentals. Real Estate Economics, $27: 2,209-230$.

Wiley, J. A., \& Wyman, D. (2012). Key factors affecting valuation for senior apartments. Journal of Real Estate Research, 34(2), 183-209. 
Table 1. Descriptive statistics for hotel property transaction sample.

\begin{tabular}{|c|c|c|c|c|c|c|}
\hline \multicolumn{7}{|c|}{ Panel A - Statistics for Selected Continuous Variables } \\
\hline Variable & Symbol & $\mathrm{N}$ & Mean & $\sigma$ & Minimum & Maximum \\
\hline Sale price & $\mathrm{P}$ & 623 & $\$ 31.3 \mathrm{M}$ & $\$ 55.1 \mathrm{M}$ & $\$ 1.6 \mathrm{M}$ & $\$ 575.0 \mathrm{M}$ \\
\hline Number of rooms & $\mathrm{RM}$ & 623 & 184 & 158 & 21 & 1348 \\
\hline $3 \mathrm{M}$ number of employees & NEMP & 623 & 6013 & 12518 & 17 & 54402 \\
\hline Effective age & EA & 623 & 15 & 20 & 1 & 113 \\
\hline City NOI & NOIC & 623 & $\$ 574535$ & $\$ 708,127$ & $\$ 30,167$ & $\$ 5,251,023$ \\
\hline Capitalization rate & $\mathrm{C}$ & 623 & $8.47 \%$ & $0.06 \%$ & $5.60 \%$ & $9.70 \%$ \\
\hline \multicolumn{7}{|c|}{ Panel B - Statistics by Categorical Variables } \\
\hline $\begin{array}{l}\text { Category } \\
\text { Market Segment }\end{array}$ & Symbol & $\mathrm{N}$ & $\begin{array}{l}\text { Sale Price } \\
\text { Mean }\end{array}$ & $\sigma$ & Minimum & Maximum \\
\hline Luxury & LUX & 28 & $\$ 105 \mathrm{M}$ & $\$ 111.1 \mathrm{M}$ & $\$ 8 \mathrm{M}$ & $\$ 575 \mathrm{M}$ \\
\hline Upper upscale & UUPS & 112 & $\$ 79.9 \mathrm{M}$ & $\$ 88.3 \mathrm{M}$ & $\$ 5.1 \mathrm{M}$ & $\$ 440 \mathrm{M}$ \\
\hline Upscale & UPS & 175 & $\$ 25.4 \mathrm{M}$ & $\$ 21.7 \mathrm{M}$ & $\$ 2.9 \mathrm{M}$ & $\$ 123 \mathrm{M}$ \\
\hline Upper midscale & UMID & 79 & $\$ 14.8 \mathrm{M}$ & $\$ 19.5 \mathrm{M}$ & $\$ 2.8 \mathrm{M}$ & $\$ 130 \mathrm{M}$ \\
\hline Midscale & MID & 134 & $\$ 11.1 \mathrm{M}$ & $\$ 11.8 \mathrm{M}$ & $\$ 2.5 \mathrm{M}$ & $\$ 73 \mathrm{M}$ \\
\hline Economy & ECO & 95 & $\$ 5.5 \mathrm{M}$ & $\$ 4.4 \mathrm{M}$ & $\$ 1.6 \mathrm{M}$ & $\$ 34 \mathrm{M}$ \\
\hline CBD Location=1 & DCBD & 153 & $\$ 70.3 \mathrm{M}$ & $\$ 81.7 \mathrm{M}$ & $\$ 2 \mathrm{M}$ & $\$ 440 \mathrm{M}$ \\
\hline CBD location $=0$ & & 470 & $\$ 18.6 \mathrm{M}$ & $\$ 34.8 \mathrm{M}$ & $\$ 1.6 \mathrm{M}$ & $\$ 575 \mathrm{M}$ \\
\hline REIT Buyer=1 & DREIT & 156 & $\$ 37.7 \mathrm{M}$ & $\$ 46.3 \mathrm{M}$ & $\$ 1.7 \mathrm{M}$ & $\$ 440 \mathrm{M}$ \\
\hline REIT Buyer=0 & & 467 & $\$ 29.2 \mathrm{M}$ & $\$ 57.6 \mathrm{M}$ & $\$ 1.6 \mathrm{M}$ & $\$ 575 \mathrm{M}$ \\
\hline Landmark=1 & DLAND & 27 & $\$ 90.8 \mathrm{M}$ & $\$ 115 \mathrm{M}$ & $\$ 6.75 \mathrm{M}$ & $\$ 440 \mathrm{M}$ \\
\hline Landmark $=0$ & & 596 & $\$ 28.6 \mathrm{M}$ & $\$ 49.3 \mathrm{M}$ & $\$ 1.6 \mathrm{M}$ & $\$ 575 \mathrm{M}$ \\
\hline Water access $=1$ & $\mathrm{DH} 2 \mathrm{O}$ & 80 & $\$ 59.3 \mathrm{M}$ & $\$ 91.2 \mathrm{M}$ & $\$ 2.5 \mathrm{M}$ & $\$ 575 \mathrm{M}$ \\
\hline Water access $=0$ & & 543 & $\$ 27.2 \mathrm{M}$ & $\$ 46.2 \mathrm{M}$ & $\$ 1.6 \mathrm{M}$ & $\$ 440 \mathrm{M}$ \\
\hline Gateway City $=1$ & DGATE & 195 & $\$ 44.6 \mathrm{M}$ & $\$ 70.9 \mathrm{M}$ & $\$ 2 \mathrm{M}$ & $\$ 440 \mathrm{M}$ \\
\hline Gateway City $=0$ & & 428 & $\$ 25.3 \mathrm{M}$ & $\$ 45 \mathrm{M}$ & $\$ 1.6 \mathrm{M}$ & $\$ 575 \mathrm{M}$ \\
\hline Renovated $=1$ & DRENO & 81 & $\$ 52.6 \mathrm{M}$ & $\$ 57.4 \mathrm{M}$ & $\$ 1.6 \mathrm{M}$ & $\$ 300 \mathrm{M}$ \\
\hline Renovated=0 & & 842 & $\$ 28.1 \mathrm{M}$ & $\$ 54.1 \mathrm{M}$ & $\$ 1.7 \mathrm{M}$ & $\$ 575 \mathrm{M}$ \\
\hline Portfolio sale $=1$ & DPORT & 146 & $\$ 23 \mathrm{M}$ & $\$ 22.3 \mathrm{M}$ & $\$ 1.7 \mathrm{M}$ & $\$ 145 \mathrm{M}$ \\
\hline Portfolio sale $=2$ & & 477 & $\$ 33.9 \mathrm{M}$ & $\$ 61.6 \mathrm{M}$ & $\$ 1.6 \mathrm{M}$ & $\$ 575 \mathrm{M}$ \\
\hline \multicolumn{7}{|l|}{ Year of Sale } \\
\hline 2005 & T05 & 155 & $\$ 30.1 \mathrm{M}$ & $\$ 63.9 \mathrm{M}$ & $\$ 2.8 \mathrm{M}$ & $\$ 424 \mathrm{M}$ \\
\hline 2006 & T06 & 100 & $\$ 42.7 \mathrm{M}$ & $\$ 69.1 \mathrm{M}$ & $\$ 2.5 \mathrm{M}$ & $\$ 440 \mathrm{M}$ \\
\hline 2007 & T07 & 179 & $\$ 27.3 \mathrm{M}$ & $\$ 56.3 \mathrm{M}$ & $\$ 1.6 \mathrm{M}$ & $\$ 575 \mathrm{M}$ \\
\hline 2008 & T08 & 108 & $\$ 25.4 \mathrm{M}$ & $\$ 43.2 \mathrm{M}$ & $\$ 2.5 \mathrm{M}$ & $\$ 367 \mathrm{M}$ \\
\hline 2009 & T09 & 37 & $\$ 21.8 \mathrm{M}$ & $\$ 29 \mathrm{M}$ & $\$ 1.6 \mathrm{M}$ & $\$ 123 \mathrm{M}$ \\
\hline 2010 & T10 & 84 & $\$ 39.6 \mathrm{M}$ & $\$ 39.1 \mathrm{M}$ & $\$ 2 \mathrm{M}$ & $\$ 166 \mathrm{M}$ \\
\hline
\end{tabular}

Note: This table presents descriptive statistics for a sample of 623 hotel real estate sales in the U.S. that occurred from 2005 through 2010.

Sources: CoStar, Moodys Analytics, PKF Hospitality Research, Real Capital Analytics, and Smith Travel Research. 
Table 2. One-stage OLS results, all hotels.

\begin{tabular}{|c|c|c|c|c|c|c|c|c|c|}
\hline \multirow{3}{*}{$\begin{array}{l}\text { Model } \\
\text { Dependent variable } \\
\text { Right-side variable label }\end{array}$} & \multirow[b]{3}{*}{ Name } & \multicolumn{2}{|l|}{$\mathrm{I}$} & \multicolumn{2}{|l|}{ II } & \multicolumn{2}{|l|}{ III } & \multicolumn{2}{|l|}{ IV } \\
\hline & & \multicolumn{2}{|l|}{$\ln (\mathrm{P})$} & \multicolumn{2}{|l|}{$\ln (\mathrm{P})$} & \multicolumn{2}{|l|}{$\ln (\mathrm{P})$} & \multicolumn{2}{|l|}{$\ln (\mathrm{P})$} \\
\hline & & Coefficient & $\mathrm{t}$ & Coefficient & $\mathrm{t}$ & Coefficient & $\mathrm{t}$ & Coefficient & $\mathrm{t}$ \\
\hline $\ln (\mathrm{NOIC})$ & City NOI & & & & & $0.4653^{*}$ & 15.51 & $0.1358^{*}$ & 4.10 \\
\hline $\ln (\mathrm{C})$ & Capitalization Rate & & & & & $-0.9430 *$ & -21.33 & $-0.5269 *$ & -7.70 \\
\hline RM & Number of Rooms & $186689 *$ & 16.12 & $0.0024 *$ & 13.81 & & & $0.0007 *$ & 2.43 \\
\hline EA & Effective Age at Date of Sale & 17068 & 0.08 & $-0.0084^{*}$ & -2.46 & & & $-0.0087^{*}$ & -2.67 \\
\hline $\mathrm{EA}^{2}$ & Effective Age Squared & -2563 & -1.02 & 0.0001 & 1.19 & & & 0.0001 & 1.56 \\
\hline NEMP & 3M Number of Employees & $34072 *$ & 7.78 & $0.0006^{*}$ & 8.43 & & & $0.0004^{*}$ & 6.47 \\
\hline DCBD & CBD Location & -3466718 & -0.75 & $0.2068^{*}$ & 2.91 & & & $0.2978^{*}$ & 4.33 \\
\hline DGATE & Gateway City & $8297052 *$ & 2.62 & $0.2970 *$ & 6.10 & & & $0.2149 *$ & 4.10 \\
\hline DLAND & Landmark Hotel & $2.53 \mathrm{e}+07 *$ & 3.38 & $0.2546^{*}$ & 2.20 & & & $0.3278^{*}$ & 2.99 \\
\hline $\mathrm{DH} 2 \mathrm{O}$ & Water Location & $1.73 e+07 *$ & 3.9 & $0.3837 *$ & 5.62 & & & $0.4088^{*}$ & 6.33 \\
\hline DRENO & Recently Renovated & $-1.09 \mathrm{e}+07 *$ & -2.36 & $0.1198 *$ & 1.68 & & & 0.0882 & 1.631 \\
\hline UUPS & Upper Upscale Chain Scale & $-3.70 \mathrm{e}+07 *$ & -4.77 & $-0.4398 *$ & -3.69 & & & $-0.3714^{*}$ & -3.24 \\
\hline UPS & Upscale Chain Scale & $-5.30 \mathrm{e}+07 *$ & -6.81 & $-0.8254^{*}$ & -6.89 & & & $-0.6617^{*}$ & -5.68 \\
\hline UMID & Upper Midscale Chain Scale & $-6.05 \mathrm{e}+07 *$ & -7.32 & $-1.2208^{*}$ & -9.59 & & & $-0.9675^{*}$ & -7.42 \\
\hline MID & Midscale Chain Scale & $-5.35 \mathrm{e}+07 *$ & -6.63 & $-1.3579 *$ & -10.93 & & & $-1.0042 *$ & -7.75 \\
\hline $\mathrm{ECO}$ & Economy Chain Scale & $-5.69 \mathrm{e}+07 *$ & -6.89 & $-1.7908 *$ & -14.09 & & & $-1.3911^{*}$ & -10.51 \\
\hline DREIT & REIT Buyer & $8681458 *$ & 2.20 & $0.3847 *$ & 6.34 & $0.4124^{*}$ & 5.84 & $0.3489 *$ & 6.07 \\
\hline
\end{tabular}




\begin{tabular}{|c|c|c|c|c|c|c|c|c|c|}
\hline \multirow{2}{*}{\multicolumn{2}{|c|}{$\begin{array}{l}\text { Model } \\
\text { Dependent variable }\end{array}$}} & \multicolumn{2}{|l|}{$\mathrm{I}$} & \multicolumn{2}{|l|}{ II } & \multicolumn{2}{|l|}{ III } & \multicolumn{2}{|l|}{ IV } \\
\hline & & \multicolumn{2}{|l|}{$\ln (\mathrm{P})$} & \multicolumn{2}{|l|}{$\ln (\mathrm{P})$} & \multicolumn{2}{|l|}{$\ln (\mathrm{P})$} & \multicolumn{2}{|l|}{$\ln (\mathrm{P})$} \\
\hline Right-side variable label & Name & Coefficient & $\mathrm{t}$ & Coefficient & $\mathrm{t}$ & Coefficient & $\mathrm{t}$ & Coefficient & $\mathrm{t}$ \\
\hline DPORT & Portfolio Sale & -1052124 & -0.29 & $0.1389 *$ & 2.46 & 0.0769 & 1.15 & $0.1268^{*}$ & 2.37 \\
\hline T06 & 1=Sold in 2006 & 7043087 & 1.43 & $0.2565^{*}$ & 3.37 & -0.0046 & -0.05 & $0.1459 *$ & 1.99 \\
\hline T07 & $1=$ Sold in 2007 & 7096943 & 1.62 & $0.2600^{*}$ & 3.86 & $-0.1960 *$ & -2.40 & $0.1335^{*}$ & 2.04 \\
\hline T08 & $1=$ Sold in 2008 & 2641751 & 0.54 & $0.2024^{*}$ & 2.71 & -1398 & -1.53 & $0.1299 *$ & 1.81 \\
\hline T09 & 1=Sold in 2009 & -6480796 & -0.96 & $0.0079 *$ & 0.08 & $0.3270^{*}$ & -2.56 & -0.0739 & -0.75 \\
\hline $\mathrm{T} 10$ & $1=$ Sold in 2010 & -5237125 & -0.96 & 0.0835 & 1.00 & -2854 & -2.75 & $-0.1393 *$ & -1.67 \\
\hline$\alpha$ & Constant & $3.15 \mathrm{e}+07 *$ & 3.44 & $16.53 *$ & 117.22 & $15.44 *$ & 220.17 & $16.32 *$ & 114.42 \\
\hline \multicolumn{10}{|l|}{$N=623$} \\
\hline $\mathrm{R}^{2}$ Adj. & & 0.5898 & & 0.7731 & & 0.6508 & & 0.7975 & \\
\hline RMSE & & $3.5 e+07$ & & 0.5437 & & 0.6746 & & 0.5136 & \\
\hline
\end{tabular}

Note: This table presents the results from regressing property characteristics, date-of-sale, and present value variables on hotel transaction prices with alternative functional forms.

*Significant at 0.10 or better. 
Table 3. Correlations and elasticity estimates

Panel A: Correlation Matrix - Selected Variables in All Hotels Regressions

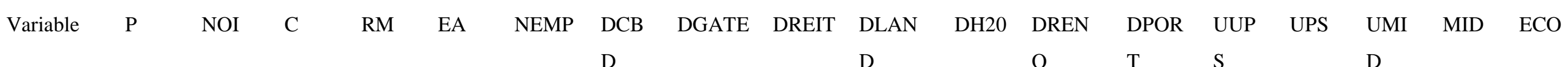

$\mathrm{P} \quad 1$

NOIC $\quad 0.45 \quad 1$

$\begin{array}{llll}\mathrm{C} & -0.35 & 0.20 & 1\end{array}$

$\begin{array}{lllll}\mathrm{RM} & 0.66 & 0.26 & -0.57 & 1\end{array}$

$\begin{array}{llllll}\text { EA } & -0.02 & 0.07 & 0.17 & -0.06 & 1\end{array}$

$\begin{array}{lllllll}\text { NEMP } & 0.35 & 0.46 & -0.03 & 0.09 & 0.09 & 1\end{array}$

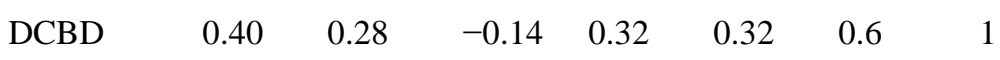

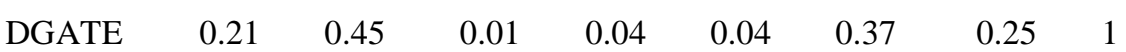

$\begin{array}{llllllllll}\text { DREIT } & 0.07 & 0.08 & -0.15 & -0.07 & -0.01 & 0.03 & 0.07 & -0.01 & 1\end{array}$

$\begin{array}{lllllllllll}\text { DLAND } & 0.23 & 0.09 & -0.05 & 0.13 & 0.13 & 0.15 & 0.27 & 0.14 & 0.01 & 1\end{array}$

$\begin{array}{llllllllllll}\text { DH20 } & 0.20 & 0.06 & -0.03 & 0.18 & 0.18 & -0.03 & 0.03 & -0.04 & -0.07 & -0.01 & 1\end{array}$

$\begin{array}{lllllllllllll}\text { DRENO } & 0.14 & 0.09 & -0.18 & 0.26 & 0.26 & 0.01 & 0.12 & 0.01 & -0.05 & 0.03 & 0.12 & 1\end{array}$

$\begin{array}{lllllllllllllll}\text { DPORT } & -0.08 & 0.01 & -0.04 & -0.12 & -0.12 & -0.05 & -0.10 & -0.02 & 0.28 & -0.06 & -0.08 & -0.11 & 1\end{array}$

$\begin{array}{lllllllllllllllll}\text { UUPS } & 0.41 & 0.27 & -0.36 & 0.53 & -0.04 & 0.07 & 0.22 & 0.09 & 0.02 & 0.13 & 0.13 & 0.34 & -0.05 & 1\end{array}$

$\begin{array}{llllllllllllllllll}\text { UPS } & -0.06 & 0.13 & -0.08 & -0.09 & -0.16 & -0.04 & -0.04 & -0.01 & 0.30 & -0.02 & 0.06 & -0.10 & 0.24 & -0.29 & 1 & 0.06\end{array}$

$\begin{array}{llllllllllllllllll}\text { UMID } & -0.11 & -0.16 & -0.01 & -0.05 & 0.06 & 0.02 & -0.07 & -0.04 & -0.19 & -0.01 & -0.04 & -0.05 & -0.18 & -0.18 & -0.23 & 1\end{array}$

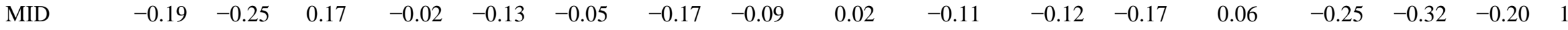

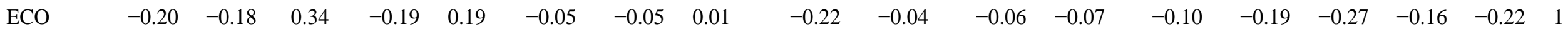

Panel B: Variance Inflation Factors (VIF)

$\begin{array}{lclc}\text { Variable } & \text { VIF } & \text { Variable } & \text { VIF } \\ \text { EA } & 9.52 & \text { DCBD } & 2.05\end{array}$




$\begin{array}{llll}\text { EA }^{2} & 9.28 & \text { T10 } & 1.91 \\ \text { DMID } & 6.57 & \operatorname{lnC} & 1.90 \\ \text { UPS } & 6.43 & \text { T08 } & 1.74 \\ \text { ECO } & 5.25 & \text { T06 } & 1.70 \\ \text { lnNOIC } & 4.87 & \text { DREIT } & 1.46 \\ \text { UUPS } & 4.54 & \text { T09 } & 1.29 \\ \text { RM } & 4.49 & \text { DRENO } & 1.21 \\ \text { UMID } & 4.37 & \text { DPORT } & 1.21 \\ \text { NEMP } & 2.14 & \text { DLAND } & 1.17 \\ \text { T07 } & 2.07 & \text { DH20 } & 1.10 \\ & & \text { Mean VIF } & 3.47\end{array}$

Panel C: Hotel Asset Price Elasticity $(\eta \mathrm{P}) * *$

Variable $\eta \mathrm{P}$

NOIC $\quad 0.0045$

C $\quad-0.0136$

RM 0.0209

EA $\quad-0.0087$

NEMP $\quad 0.0059$

Note: This table reports correlations and elasticity estimates among variables in the property regression models from Table 2.

Sources: CoStar, Moodys Analytics, PKF Hospitality Research, Real Capital Analytics, and Smith Travel Research

**Elasticity only reported for continuous variables because of interpretational difficulty 
Table 4. Two-stage ls results, all hotels.

\begin{tabular}{|c|c|c|c|}
\hline \multirow{2}{*}{$\begin{array}{l}\text { Dependent variable } \\
\text { Right side variable label }\end{array}$} & \multirow[b]{2}{*}{ Name } & \multicolumn{2}{|l|}{$\ln (\mathrm{P})$} \\
\hline & & Coefficient & $\mathrm{z}$ \\
\hline $\ln (\mathrm{NOIC})$ & City NOI & $0.2239 *$ & 7.74 \\
\hline $\ln (\mathrm{C})$ & Capitalization Rate & $-0.5195^{*}$ & -7.66 \\
\hline RM & Number of Rooms & 0.0006 & 2.28 \\
\hline EA & Effective Age at Date of Sale & $-0.0079 *$ & -2.46 \\
\hline $\mathrm{EA}^{2}$ & Effective Age Squared & 0.0001 & 1.42 \\
\hline NEMP & 3M Number of Employees & $0.0001 *$ & 6.59 \\
\hline DCBD & CBD Location & $0.3222 *$ & 4.74 \\
\hline DLAND & Landmark Hotel & $0.3641 *$ & 3.36 \\
\hline DH20 & Water Location & $0.4014 *$ & 6.27 \\
\hline DRENO & Recently Renovated & 0.0801 & 1.20 \\
\hline UUPS & Upper Upscale Chain Scale & $-0.3321 *$ & -2.93 \\
\hline UPS & Upscale Chain Scale & $-0.6281^{*}$ & -5.45 \\
\hline UMID & Upper Midscale Chain Scale & $-0.9133^{*}$ & -7.12 \\
\hline MID & Midscale Chain Scale & $-0.9454 *$ & -7.42 \\
\hline ECO & Economy Chain Scale & $-1.3349 *$ & -10.26 \\
\hline DREIT & REIT Buyer & $0.3403 *$ & 5.98 \\
\hline DPORT & Portfolio Sale & $0.1205^{*}$ & 2.27 \\
\hline T06 & 1=Sold in 2006 & $0.1298 *$ & 1.79 \\
\hline T07 & $1=$ Sold in 2007 & $0.1428 *$ & 2.20 \\
\hline T08 & $1=$ Sold in 2008 & $0.1273 *$ & 1.79 \\
\hline T09 & 1=Sold in 2009 & -0.0678 & -0.69 \\
\hline T10 & 1=Sold in 2010 & -0.1361 & -1.65 \\
\hline$\alpha$ & Constant & $16.27 *$ & 115.24 \\
\hline $\mathrm{N}$ & 623 & & \\
\hline R2 & 7991 & & \\
\hline RMSE & 0.5112 & & \\
\hline
\end{tabular}

Note: This table presents the results from regressing property characteristics, date-of-sale, and present value variables on hotel transaction prices with alternative functional forms

Sources: CoStar, Moodys Analytics, PKF Hospitality Research, Real Capital Analytics, and Smith Travel Research

*Significant at 0.10 or better 
Table 5. Variation in selected implicit prices, 2005-2010.

\begin{tabular}{lll}
\hline Variable Label & Name & Implicit price range \\
\hline RM & Number of Rooms & .0009 to .0034 \\
EA & Effective Age at Date of Sale & .0015 to .0233 \\
NEMP & 3M Number of Employees & .0004 to .0010 \\
DCBD & CBD Location & -.1473 to .4184 \\
DLAND & Landmark Hotel & -.0732 to .7520 \\
DH2O & Water Location & .1203 to .5331 \\
DRENO & Recently Renovated & -.0809 to .7414 \\
UUPS & Upper Upscale Chain Scale & -.8167 to -.2766 \\
UPS & Upscale Chain Scale & -1.3924 to -.2500 \\
UMID & Upper Midscale Chain Scale & -1.6615 to -.7725 \\
MID & Midscale Chain Scale & -1.7674 to -.7478 \\
ECO & Economy Chain Scale & -2.2282 to -1.9583 \\
DREIT & REIT Buyer & .2207 to .6775 \\
DPORT & Portfolio Sale & -.0608 to 2108 \\
$\alpha$ & Constant & 16.08 to 17.49 \\
\hline
\end{tabular}

Notes: This table presents the range of implicit prices for selected determinants in a single-stage regression only with property-specific variables estimated each year from 2005-2010.

Sources: CoStar, Moodys Analytics, PKF Hospitality Research, Real Capital Analytics, and Smith Travel Research. 
Table 6. One- and two-stage LS results, luxury and upper upscale hotels.

\begin{tabular}{|c|c|c|c|c|c|}
\hline \multirow{2}{*}{\multicolumn{2}{|c|}{$\begin{array}{l}\text { Stage regression } \\
\text { Dependent variable }\end{array}$}} & \multirow{2}{*}{\multicolumn{2}{|c|}{$\frac{\text { Single }}{\ln (\mathrm{P})}$}} & \multicolumn{2}{|l|}{ Two } \\
\hline & & & & $\ln (\mathrm{P})$ & \\
\hline Right side variable label & Name & Coefficient & $\mathrm{t}$ & Coefficient & $\mathrm{z}$ \\
\hline $\ln (\mathrm{NOIC})$ & City NOI & $.2452 *$ & 3.47 & $.3242 *$ & 5.30 \\
\hline $\ln (\mathrm{C})$ & Capitalization Rate & $-.7205^{*}$ & -3.90 & $-.7350 *$ & -4.29 \\
\hline RM & Number of Rooms & .00016 & 0.34 & .0001 & 0.26 \\
\hline EA & Effective Age at Date of Sale & -.0135 & -1.66 & -.0128 & -1.69 \\
\hline $\mathrm{EA}^{2}$ & Effective Age Squared & .0001 & 1.16 & .0001 & 1.09 \\
\hline NEMP & 3M Number of Employees & $.0004^{*}$ & 2.70 & $.0004^{*}$ & 2.92 \\
\hline DCBD & CBD Location & $.3267 *$ & 2.35 & $.3349^{*}$ & 2.60 \\
\hline DGATE & Gateway City & .1503 & 1.14 & N/A & N/A \\
\hline DLAND & Landmark Hotel & .2433 & 1.28 & .2802 & 1.62 \\
\hline DH2O & Water Location & $.3426^{*}$ & 2.52 & $.3809 *$ & 2.56 \\
\hline DRENO & Recently Renovated & .0411 & 0.37 & .0379 & 0.36 \\
\hline DREIT & REIT Buyer & $.3241 *$ & 2.22 & $.3122^{*}$ & 2.32 \\
\hline DPORT & Portfolio Sale & .0045 & 0.03 & -.0151 & -0.11 \\
\hline T06 & 1=Sold in 2006 & .2038 & 1.14 & .1940 & 1.16 \\
\hline T07 & 1=Sold in 2007 & .2904 & 1.62 & $.3087 *$ & 1.88 \\
\hline T08 & $1=$ Sold in 2008 & .2581 & 1.21 & .2766 & 1.41 \\
\hline T09 & 1=Sold in 2009 & -.1939 & -0.74 & -.1742 & -0.72 \\
\hline $\mathrm{T} 10$ & 1=Sold in 2010 & -.1431 & -0.69 & -.1097 & -0.58 \\
\hline$\alpha$ & Constant & $15.82^{*}$ & 72.33 & $15.73^{*}$ & 77.14 \\
\hline \multicolumn{6}{|l|}{$N=140$} \\
\hline $\mathrm{R}^{2}$ & Adjusted & .6020 & & .6479 & \\
\hline RMSE & Root Mean Square Error & .6023 & & .5644 & \\
\hline
\end{tabular}

Note: This table presents the results from regressing property characteristics, date-of-sale, and present value variables on luxury and upper upscale hotel transaction prices using both singleand two-stage models

Sources: CoStar, Moodys Analytics, PKF Hospitality Research, Real Capital Analytics, and Smith Travel Research

*Significant at .10 or better 
Table 7. One- and two-stage LS results, upscale and upper midscale hotels.

\begin{tabular}{|c|c|c|c|c|c|}
\hline \multirow{2}{*}{\multicolumn{2}{|c|}{$\begin{array}{l}\text { Stage regression } \\
\text { Dependent variable }\end{array}$}} & \multirow{2}{*}{\multicolumn{2}{|c|}{$\begin{array}{l}\text { Single } \\
\ln (\mathrm{P})\end{array}$}} & \multicolumn{2}{|l|}{ Two } \\
\hline & & & & $\ln (\mathrm{P})$ & \\
\hline Right side variable label & Name & Coefficient & $\mathrm{t}$ & Coefficient & $\bar{Z}$ \\
\hline $\ln (\mathrm{NOIC})$ & City NOI & $.2127 *$ & 4.50 & $.3081^{*}$ & 7.82 \\
\hline $\ln (\mathrm{C})$ & Capitalization Rate & $-.5563^{*}$ & -3.60 & $-.5799 *$ & -3.88 \\
\hline $\mathrm{RM}$ & Number of Rooms & .0001 & 0.00 & -.0002 & -0.27 \\
\hline EA & Effective Age at Date of Sale & $-.0120 *$ & -2.29 & $-.0118 *$ & -2.32 \\
\hline $\mathrm{EA}^{2}$ & Effective Age Squared & $.0001^{*}$ & 2.04 & $.0001^{*}$ & 2.10 \\
\hline NEMP & 3M Number of Employees & $.0003^{*}$ & 2.69 & $.0003 *$ & 2.70 \\
\hline DCBD & CBD Location & $.4802 *$ & 4.31 & $.5001 *$ & 4.65 \\
\hline DGATE & Gateway City & $.2029 *$ & 2.38 & N/A & N/A \\
\hline DLAND & Landmark Hotel & $.3669 *$ & 1.86 & $.3649 *$ & 1.90 \\
\hline $\mathrm{DH} 2 \mathrm{O}$ & Water Location & $.6263^{*}$ & 6.18 & $.6389 *$ & 6.51 \\
\hline DRENO & Recently Renovated & $.2232 *$ & 1.77 & $.2195^{*}$ & 1.80 \\
\hline DREIT & REIT Buyer & $.3930 *$ & 4.64 & $.3812 *$ & 4.67 \\
\hline DPORT & Portfolio Sale & $.1539^{*}$ & 1.93 & $.1403^{*}$ & 1.82 \\
\hline T06 & $1=$ Sold in 2006 & .1874 & 1.65 & .1569 & 1.42 \\
\hline T07 & $1=$ Sold in 2007 & .1539 & 1.51 & .1310 & 1.32 \\
\hline T08 & $1=$ Sold in 2008 & .0878 & 0.80 & .0656 & 0.61 \\
\hline T09 & $1=$ Sold in 2009 & .1526 & 0.86 & .1450 & 0.84 \\
\hline $\mathrm{T} 10$ & $1=$ Sold in 2010 & -.0454 & -0.35 & -.0917 & -0.73 \\
\hline$\alpha$ & Constant & 15.48 & $\begin{array}{l}116.7 \\
8\end{array}$ & $15.49^{*}$ & 121.23 \\
\hline \multicolumn{6}{|l|}{$N=254$} \\
\hline $\mathrm{R}^{2}$ & Adjusted & .5911 & & .6094 & \\
\hline RMSE & Root Mean Square Error & .5215 & & .5087 & \\
\hline
\end{tabular}

Note: This table presents the results from regressing property characteristics, date-of-sale, and present value variables on upscale and upper midscale hotel transaction prices using both singleand two-stage models

Sources: CoStar, Moodys Analytics, PKF Hospitality Research, Real Capital Analytics, and Smith Travel Research

*Significant at .10 or better 
Table 8. One- and two-stage LS results, midscale and economy hotels.

\begin{tabular}{|c|c|c|c|c|c|}
\hline \multirow{2}{*}{\multicolumn{2}{|c|}{$\begin{array}{l}\text { Stage regression } \\
\text { Dependent variable }\end{array}$}} & \multirow{2}{*}{\multicolumn{2}{|c|}{$\frac{\text { Single }}{\ln (\mathrm{P})}$}} & \multicolumn{2}{|l|}{ Two } \\
\hline & & & & $\ln (\mathrm{P})$ & \\
\hline Right side variable label & Name & Coefficient & $\mathrm{t}$ & Coefficient & $\mathrm{z}$ \\
\hline $\ln (\mathrm{NOIC})$ & City NOI & 0.0424 & 0.66 & $0.1750 *$ & 3.23 \\
\hline $\ln (\mathrm{C})$ & Capitalization Rate & $-0.5013^{*}$ & -3.13 & $-0.5185^{*}$ & -3.36 \\
\hline $\mathrm{RM}$ & Number of Rooms & -0.0002 & -0.14 & -0.0005 & -0.38 \\
\hline EA & Effective Age at Date of Sale & $-0.0112 *$ & -2.29 & $-0.0105^{*}$ & -2.25 \\
\hline $\mathrm{EA}^{2}$ & Effective Age Squared & 0.00002 & 0.29 & 0.00002 & 0.34 \\
\hline NEMP & 3M Number of Employees & $0.0005^{*}$ & 4.40 & $0.0005^{*}$ & 4.35 \\
\hline DCBD & CBD Location & 0.1665 & 1.23 & 0.1987 & 1.53 \\
\hline DGATE & Gateway City & $0.1952^{*}$ & 2.33 & N/A & N/A \\
\hline DLAND & Landmark Hotel & -0.0811 & -0.23 & -0.0521 & -0.16 \\
\hline DH2O & Water Location & 0.1361 & 1.03 & 0.1329 & 1.04 \\
\hline DRENO & Recently Renovated & -0.0807 & -0.51 & -0.0940 & -0.61 \\
\hline DREIT & REIT Buyer & $0.5230^{*}$ & 4.90 & $0.5066^{*}$ & 4.92 \\
\hline DPORT & Portfolio Sale & $0.2067 *$ & 2.34 & $0.2185^{*}$ & 2.56 \\
\hline T06 & 1=Sold in 2006 & 0.1173 & 0.91 & 0.0462 & 0.37 \\
\hline T07 & $1=$ Sold in 2007 & 0.0012 & 0.01 & -0.0461 & -0.46 \\
\hline T08 & $1=$ Sold in 2008 & 0.1278 & 1.13 & 0.0611 & 0.56 \\
\hline T09 & 1=Sold in 2009 & -0.1335 & -0.92 & -0.1748 & -1.24 \\
\hline $\mathrm{T} 10$ & 1=Sold in 2010 & -0.1659 & -1.09 & -0.2042 & -1.39 \\
\hline$\alpha$ & Constant & $15.45^{*}$ & 97.91 & $15.49 *$ & 102.28 \\
\hline \multicolumn{6}{|l|}{$N=229$} \\
\hline $\mathrm{R}^{2}$ & Adjusted & 0.5607 & & 0.5824 & \\
\hline RMSE & Root Mean Square Error & 0.4734 & & 0.4606 & \\
\hline
\end{tabular}

Note: This table presents the results from regressing property characteristics, date-of-sale, and present value variables on midscale and economy hotel transaction prices using both single- and two-stage models.

Sources: CoStar, Moodys Analytics, PKF Hospitality Research, Real Capital Analytics, and Smith Travel Research.

*Significant at .10 or better 